\title{
Ataxia-deafness-intellectual disability syndrome
}

INSERM

\section{Source}

INSERM. (1999). Orphanet: an online rare disease and orphan drug data base. Ataxiadeafness-intellectual disability syndrome. ORPHA:1188

This syndrome is characterised by progressive ataxia beginning during childhood, deafness and intellectual deficit. 